\title{
May China Fish in the Arctic Ocean?
}

\author{
Yen-Chiang Chang ${ }^{1}(\mathbb{D}$ and Mehran Idris Khan $1,2, * \mathbb{D}$ \\ 1 School of Law, Dalian Maritime University, Dalian 116026, China; ycchang@dlmu.edu.cn \\ 2 Faculty of Law, University of Sialkot, Sialkot 51310, Pakistan \\ * Correspondence: Ifomd@hotmail.com
}

\section{check for} updates

Citation: Chang, Y.-C.; Khan, M.I. May China Fish in the Arctic Ocean? Sustainability 2021, 13, 11875.

https://doi.org/10.3390/su132111875

Academic Editor: Tim Gray

Received: 7 October 2021

Accepted: 26 October 2021

Published: 27 October 2021

Publisher's Note: MDPI stays neutral with regard to jurisdictional claims in published maps and institutional affiliations.

Copyright: (c) 2021 by the authors. Licensee MDPI, Basel, Switzerland. This article is an open access article distributed under the terms and conditions of the Creative Commons Attribution (CC BY) license (https:// creativecommons.org/licenses/by/ $4.0 /)$.

\begin{abstract}
In addition to the traditional so-called Arctic states, non-Artic states and some other international organisations are now showing a growing interest in this area. China, for example, has achieved some progress, since becoming an Arctic Council permanent observer, through participation in resource development in the region and strengthening its bilateral relations with the Arctic states. The present study examines China's Arctic policy and its implications for the governance of the Arctic Ocean. It also provides an insight into the existing relevant international legal instruments and examines China's interest in the participation, governance, and resource protection activities in the Arctic Ocean region, to successfully implement Chinese Arctic policy. To this end, the study examines the connection between the "white paper" and "China's Arctic Policy", in the context of executing the "Belt and Road Initiative", in particular the "Arctic Silk Road". The study concludes that China intends to perform a dynamic role in governing the Arctic Ocean, as a less challenging but cooperative partner in this region.
\end{abstract}

Keywords: China's white paper for Arctic policy; fisheries resources; Arctic Ocean; Chinese legal rights

\section{Introduction}

Over the past 15 years, the ice of the Central Arctic Ocean (CAO) has been increasingly melting and thus, offering new opportunities for international navigation [1]. For example, in the summer of 2012, around $40 \%$ of the CAO was covered with ice and thus appeared as unexplored open water on maps [2]. In recent times, new ocean access can be observed for the first time in many years of known history. In addition, as global warming increases, the probability of an ice-free Arctic Ocean increases in the coming years [3].

It is a fact that the fish stock of the Arctic is moving towards the sub-Arctic waters [4], with the summer retreat of the sea ice and the warming of the oceanic waters [5]. This combination of species in open waters and fishery stocks moving north increases the prospect of fishing in the Arctic, although it is as yet unclear which species, in what numbers and when, might arrive in the $\mathrm{CAO}$ waters [6]. Fish governance in the $\mathrm{CAO}$ has, however, become a more demanding problem as regards the governance of the Arctic Ocean, beyond national jurisdiction. The five Arctic states signed the Declaration to Prevent Unregulated Deep-Sea Fisheries in the Central Arctic Ocean [7], in July 2015, including noting their intention to develop further comprehensive international agreement(s) based on these principles [8].

Usually, such issues are addressed as social or economic issues, which subsequently create political interests and lead to final planning and policymaking; fishing in the open waters of the Bering Sea, known as the Donut Hole, shows evidence of this pattern [9]. Scientific efforts have helped to establish governance goals for fish stocks and support effective management [10]. The signing of the Agreement to Prevent Unregulated High Seas Fisheries in the Central Arctic Ocean by Arctic states, together with other non-Arctic states (China, Korea, Japan, and Iceland and the European Union), has developed a legal euphoria [11]. These five Arctic coastal states joined a group of non-Arctic states for the first time, to reach a legally binding agreement concerning specific issues in the Arctic 
region; this legal development recognises that there is currently no ongoing commercial fishing within the high seas of the Arctic region [12]. As a result of the aforementioned, a distinguishing feature of this agreement can be identified as acceptance of the precautionary principle of international law.

On the other side of the coin, China has perceived itself as a "Near Arctic State"; what occurs in the Arctic Ocean region is having a progressively substantial impact on China, and it is also true that climate change and the ecosystems in the Arctic Ocean can have an impact on the Chinese climate, which in turn could have a significant impact on overall living conditions, especially concerning agricultural production in China [8]. In addition to potential navigation through the Arctic, the commercial exploitation of the Arctic Sea lanes also has potential implications for trade and economic development in China. Such developments as those concerning the oil and mineral resources in the Arctic Ocean region are of significant Chinese interest, as an important manufacturer of industrial goods, as well as a consumer of raw materials [13].

Concerning the participation in the Arctic Ocean region, China claims to have a long history, as evidenced by the signing of the Svalbard Treaty 1925 [14], and the opening of the Huang He research station in Ny-Ålesund in 1925 and 2004, respectively [15]. In addition, since 1999, China has led six scientific tours to the Arctic region and committed to running similar trips every two years, from 2012 onwards. Later, Chinese scientists made the state's first transaction voyage to Iceland from Shanghai, aboard the Xuelong (Snow Dragon) icebreaker, in August 2012 [16]. There are several goals of Chinese scientific expeditions to the Arctic Ocean region, including marine biological research, aurora observations, and environmental concerns.

China understood in earlier years that working with Arctic coastal states was the ideal way for it to participate in various Arctic-related issues [17]. For this purpose, China has also been periodically and significantly investing in various fields of Arctic states, e.g., in March 2015, in cooperation with Russian gas company, Novatek, China made available USD 15 billion to finance a USD 27 billion plant for liquefied natural gas (LNG) on the Russian Yamal peninsula [18]. Furthermore, in collaboration with London Mining in the UK, a Chinese company attempted to create an Isua iron ore mine in Greenland. That venture failed, however, with the bankruptcy of London Mining resulting from plunging iron ore prices, but the Chinese corporation retained the exploration rights of Isua and acquired the subsidiary of London Mining, which was based in Greenland. Later, in 2015, a Chinese private trading company (the General Nice Group) took over a large iron ore mine in Greenland, which was valued at around USD 2 billion [19]. In addition to this, some Chinese corporations have also been concerned about making significant investments in local infrastructure in the Arctic states [20].

Moreover, the potential of the fishery stocks in the CAO is also a great source of attraction for the growing Chinese economy and its global diplomatic mission of expanding and growing peacefully. Chinese demand for fish has grown significantly with the rapid rise in income of many of the Chinese population, as well as the collapse of fish stock resources in its near-shore areas [8]. These demands have led to the recent improvements in and the expansion of the deep-sea fishing fleet in China. It is also notable that experts from the Chinese Academy of Social Sciences have suggested that overseas fishing could best suit the long-term priority of agricultural development in China [21]. China may, thus, wish to increase its presence in fishing around the globe, including participating in governance, conservation, and resource development activities in the Arctic Ocean region.

The methodology employed in this article is based on the qualitative data analysis of working papers, national policy documents, international and regional agreements, academic journals, books, key newspaper articles, reports, and other important relevant electronic materials including international organisations. It draws on the literature and content analysis method to qualitatively analyse the Arctic governance policies of the Arctic states and other major stakeholders. By doing so, however, the main focus of this article is China's role in Arctic governance as represented by its Arctic policy and future prospects, 
i.e., China's White Paper-Arctic Policy, which is highly representative of how China deals with Arctic governance and supports its claim of being a near-Arctic state promoting its stances of co-existence and the sustainable future use of the Arctic fisheries. To this end, Section 2 provides insight into China's views on the Arctic Ocean. Section 3 examines Chinese Arctic policy as laid down in its white paper, including its participation in the governance, conservation, resource development and protection, and utilisation of fish stocks and other living resources, as well as the routes of the Arctic Ocean as part of the Polar Silk Road (PSR) and the Belt and Road Initiative (BRI). Section 4 provides an analysis of the available existing international treaties and legal agreements concerning fishing issues in the Arctic Ocean region. Similarly, Section 5 presents the logic and reasoning of China's future role in the Arctic, followed by concrete concluding remarks in Section 6.

\section{China's Views on International Cooperation in the Arctic Ocean}

The fact of the continuing melting of the Arctic sea ice poses grave security and sovereignty challenges, which are gradually manifested in developing relationships between both the Arctic states and non-Arctic states such as Japan, China, India, and South Korea [22]. International cooperation concerning the Arctic Ocean region needs to be strengthened. Most Arctic issues are critically national; however, some are also regional and international, i.e., problems related to resource development, navigation, and environmental effects of climate change. These problems need deeper consideration of the causes and effects of natural variability and man-made ecological variations in the Arctic Ocean. Global cooperation in the Arctic region is increasingly expanding over time, creating significant challenges as well as enormous potential in the area. The history of such international collaboration in the Arctic goes back to the early 1990s, emphasising scientific research and environmental protection, but this swiftly extended to include sustainable development [23]. International cooperation among the states around the Arctic and other non-Arctic states has developed on some levels bilaterally or within the framework of the existing regional forums and international organisations, in the sphere of sustainable development, ecological protection, and scientific research.

In 2015, at the third meeting of the Arctic Circle held in Iceland, the then Deputy Foreign Minister of China delivered a keynote address entitled "China in the Arctic: Policies and Practices" [24]. The next year, China's chief climate change negotiator delivered another speech at the Fourth Assembly of the Arctic Circle on China's vision of working together in the Arctic [25]. These speeches and the way forward used the key word "cooperation" in the Arctic, which highlighted an emerging Chinese Arctic policy. Recognition and respect for mutual rights is the basis for international legal cooperation between the Arctic and non-Arctic states. The United Nations Convention of the Law of the Sea (UNCLOS) [26] provides the Arctic states with the rights over jurisdiction as well as sovereignty, as regards their particular coastal areas of the Arctic Ocean. Similarly, non-Artic states also enjoy the rights of navigation and scientific research [27]. In order to develop a partnership in the Arctic region, all these states should act primarily based on mutual recognition and respect for the relevant provisions of international law.

Secondly, trust and mutual understanding offer political assurance for cooperation between these states. Arctic states, which have a greater interest in Arctic-related affairs, claim to be entitled to play a more dominant role in these affairs than that of non-Arctic states. Given the supra-regional impact of some Arctic-related problems, such as environmental impact, non-Arctic states also claim to have legitimate interests in matters relating to the Arctic Ocean [28]. There is no doubt that all these states will perform a progressively important part in Arctic affairs, with all interests being linked. In order to strengthen cooperation, all the concerned states should strive to improve their trust and mutual understanding, strengthen communication, mutual assistance and support, and seek convergent areas of interest, based on mutual respect for their rights.

Thirdly, the treatment of supra-regional problems through joint research efforts is an important field of cooperation among various states which claim their interest in the Arctic 
Ocean. Increased trust and mutual assistance in scientific research will enable these states to consider supra-regional problems from a broader perspective, sending a broader message to the global scientific community while also appropriately simplifying the processes of resolution of pertinent problems. This collaboration model has already produced promising results in addressing issues, for example, Artic shipping and climate change [22]. The problem for the Arctic Council members is now to include the non-Arctic states in related scientific research and other comprehensive discussions at an early stage [29].

There are different specific interests, rights, and concerns between the Arctic and non-Arctic states concerning Arctic affairs: sustainable development, stability, and peace in the Arctic Ocean, however, serve the common interests of all states concerned. International cooperation and partnerships concerning mutual benefits that strengthen and promote these interests will certainly be the most suitable path in this region of increasingly internationally significance. Given the situation, "respect" is the fundamental basis for Chinese participation in Arctic-related affairs; therefore, "cooperation" could be an effective vehicle for Chinese Arctic policy. This can be a win-win situation for Chinese participation in various affairs or activities in the Arctic Ocean, by encouraging the message that all parties involved in all areas of activity should seek mutual benefit and mutual progress. China's interests typically range from promoting bilateral Arctic diplomacy to participating in the governance of Arctic affairs, as well as access to resource exploitation opportunities and exploration [30]. So far, Chinese involvement in the Arctic region has been relatively modest. In 2013, China gained observer status with the Arctic Council and slightly strengthened its bilateral relationships with some of the surrounding states, especially Iceland and Finland, while participating in various Arctic-related activities, i.e., resource development in the region [31].

The newly issued Chinese white paper concerning its Arctic policy indicates that the Arctic's political goals concern four basic principles-understanding, protection, development, and participation in Arctic governance. This stresses the need for "cooperation, sustainability, respect, and win-win results" to achieve these political goals. Chinese strategy concerning the Arctic is just beginning to evolve and is still facing several challenges, including the natural environment in the Arctic Ocean, coupled with technological constraints, disputes among the Arctic states on the issues concerning territorial sovereignty, and security activities between certain states. In sum, with the recently published Chinese Arctic policy, the white paper, China strategically highlighted a crucial issue in the future of Arctic affairs, that of cooperation.

\section{China's Arctic Policy-'White Paper'}

China published its first white paper concerning its Arctic policy in January 2018. China has stated that its political goals as a major stakeholder as well as a "Near Arctic State" are to participate, protect, understand, and develop Arctic governance, in order to protect the common interests of the international community concerning the communities in the Arctic and, eventually, to promote sustainable development [32]. Thus, as a rising power, China primarily wants to understand the Arctic to use and protect this resource-rich region [11]. However, the question arises as to how China will attempt to reconcile the use and protection of natural resources in the Arctic region, bearing in mind progress to date.

As indicated in the white paper, Chinese Arctic policies should not, however, be seen as a revelation but as a confirmation of its existing policy. Chinese officials formulated the content of the white paper in previous years; these basic principles and political goals of its participation in the Arctic have already been raised several times by Chinese officials [33]. It is pertinent to mention here that all Arctic and some observer states have published their corresponding strategy documents concerning their Arctic policies. The conclusion of Chinese Arctic politics is relatively new, as compared to those of the other Arctic states, and is still in progress [34]. In contrast to its Western counterparts, China only outlines its policy in writing where it is obliged to do so or when it is in its best interests. The publication of the white paper, therefore, shows how important the Arctic is to policymakers. 
In the above discussion and guidelines, it appears that the white paper stresses Chinese adherence to international law and the framework of international treaties. For example, with regard to scientific research, China expressed respect for the sovereign rights and jurisdiction of the Arctic states while, simultaneously, the freedom of scientific research and exploitation, as well as exploration of all high seas in the Arctic Ocean region, are essentially respected [33]. Similarly, it argues that further developments of shipping routes in the Arctic must also comply with international law, UNCLOS, and the freedom of navigation [27].

3.1. Chinese Participation in the Governance, Conservation, Resource Protection, and Utilisation of Fisheries and Other Living Resources in the Arctic

It is an acknowledged fact that the Arctic Ocean region has the potential to become a new fishing area, with fish stocks tending to move north due to various factors, including climate change [35]. With regard to deep-sea fishing in the Arctic region, China has continuously taken a strong stance in favour of scientific research, resource protection, and sustainable utilisation. While China enjoys the legitimate right to conduct marine scientific research and development in the Arctic region, all relevant states should continue to meet their legal obligations to conserve the ecosystem and fish stocks in the region [36].

As part of China's most recent Arctic policy, the country is supporting efforts to draft a legally binding universal treaty on the conservation and governance of fish stocks concerning the Arctic Ocean. China also supports the creation of an organisation concerning the protection and governance of Arctic fisheries or other similar institutional measures, on the basis of relevant provisions of UNCLOS. In this way, China will increase the study and exploration of deep-sea fishing resources in the Arctic, conduct appropriate fishing activities, and form a productive part in the organisation of deep-sea fishing in the Arctic. It is a fact that China hopes to support mutual cooperation with the Arctic States in the areas of governance, resource development, conservation, exploration, and the use of potential fish stocks in the Arctic Ocean. China is also committed to the appropriate protection of Arctic biodiversity, clear and sensible exploration and exploitation, sustainable use of the genetic resources of the Arctic region, and reasonable sharing and exploitation of the benefits arising from the use of these Arctic resources.

Globally, China claims to actively participate in formulating the rules relating to deepsea fishing governance, the global environment, international marine affairs, and climate change, and fulfils its international obligations under international law. China is expanding its support and collaboration with several states and global organisations in promoting energy-saving and environmental protection, low carbon development, and emission reduction [37]. China also encourages cooperation in combating the issues of climate change and maintains the principles of fairness and shared but differentiated responsibility under the Paris Agreement [38], the Kyoto Protocol [39], and the UN Framework Convention on Climate Change [40], and supports developing countries in combating the issues of climate change [41]. Similarly, China also claims to play a productive part in various activities under the International Maritime Organisation (IMO) and is making significant efforts to meet its global obligations to ensure the safety of shipping by preventing its ships from creating marine environmental pollution, while supporting greater global cooperation in the area of marine technology and research as regards the shipping industry, within the framework of the IMO [42]. China is actively participating in negotiations on the regulation of deep-sea fish stocks in the Arctic region and is calling for a legally binding international treaty for the development, protection, and governance of fish resources on the high seas in this region [43]. It urges that such a globally binding treaty should enable exploratory fishing activities and appropriate scientific research on the high seas in the Arctic region, as well as protecting the freedom of all states' rights on the high seas under the pertinent provisions of UNCLOS and international law.

The white paper underscores Chinese interests in the lawful and rational use of Arctic resources. China reaffirms that it respects the Arctic states' sovereign rights over minerals, gas, and oil and fishery resources in the areas for which they are responsible 
under international law and respects the concerns and interests of the residents of the residents Arctic region [22]. Of the five Arctic coastal states, Canada is most concerned about the impact of the Chinese Arctic policy, as laid down in the white paper. Canadian experts caution that the Chinese Arctic policy may try to draw a fine line between respecting the sovereignty of the Arctic states and the possibility of benefiting from international disputes [44]. An expert, Robert Huebert, sees the use of language such as "respect for international law" in the Chinese Arctic policy in the white paper as an attempt to articulate the limits of the sovereignty of the Arctic states [45]. Among the issues about which Canada is most concerned is whether China will have the same legal position as the European Union (EU) and the United States (US): to treat the Northwest Passage as a "road for international use", contrary to what Canada claims as "internal waters" [46]. By means of its Arctic policy, however, China claims that it largely avoids this complicated problem and instead focuses on the significant opportunities as well as possible challenges that may arise from environmental and economic considerations. As shown in Table 1, China holds a long history of engagement in the various aspects concerning the Arctic Ocean, including science and technology, management, cooperation, ocean governance, and sustainable fisheries across the region.

Table 1. Chinese chronological history of engagement in the Arctic Ocean.

\begin{tabular}{|c|c|}
\hline Description & Year \\
\hline Chinese scientists took part in the first International Polar Year & 1882 \\
\hline China signed Spitsbergen Treaty & 1925 \\
\hline First Chinese participation in Soviet research in the Arctic & 1951 \\
\hline $\begin{array}{l}\text { State Oceanic Administration was established, with a brief to "engage in polar } \\
\text { expeditions in the future" }\end{array}$ & 1964 \\
\hline China took a seat in United Nations and Security Council & 1971 \\
\hline Visits to the Arctic-Chinese Academy of Sciences sets up Polar Science Committee & 1995 \\
\hline China Arctic and Antarctic Administration was set up & 1996 \\
\hline China joined International Arctic Science Committee & 1996 \\
\hline $\begin{array}{l}\text { China Arctic and Antarctic Administration dispatched Xue Long (ship) on the first } \\
\text { Arctic expedition }\end{array}$ & 1999 \\
\hline $\begin{array}{c}\text { Opening of the temporary research station China Yilite-Mornring Arctic Scientific } \\
\text { Expedition and Research Station on Svalbard, Norway }\end{array}$ & 2001 \\
\hline Opening of permanent Arctic Yellow River Station on Svalbard, Norway & 2004 \\
\hline China accepted for the first time as a temporary observer on the Arctic Council & 2007 \\
\hline China accepted as a permanent observer on the Arctic Council & 2013 \\
\hline Chinese President, $\mathrm{Xi}$ Jinping, says China strives to be a "polar great power" & 2014 \\
\hline $\begin{array}{l}\text { Chinese Communist Party identified the polar regions, the deep seabed, and outer } \\
\text { space as China's new strategic frontiers }\end{array}$ & 2015 \\
\hline Xue Long sets off on seventh Arctic expedition & 2016 \\
\hline $\begin{array}{l}\text { Chinese Communist Party reshuffle integrates Arctic and maritime policy within } \\
\text { geopolitical strategy making }\end{array}$ & 2018 \\
\hline Chinese Arctic Policy White Paper announced the Polar Silk Road & 2018 \\
\hline
\end{tabular}

\subsection{The Routes of the Arctic Ocean as Part of the BRI}

Scientific researchers such as Camilla Sørensen and Yağci (2018) have argued that the Arctic Ocean routes have been the central element of Arctic diplomacy in China for some time and its Arctic policy in the recent legal development is inadequate in the current situation [47]. In a related area, however, the Arctic states are opening up the novel 
and unique opportunities for trade and development. This concerns China's political goal of contributing to the development of the routes of the Arctic Ocean, which China believes may become a reality possible for commercial purposes earlier than is generally expected. China claims that the routes of the Arctic Ocean can be an attractive alternative to the strategically endangered routes passing through the Suez Canal and the Straits of Malacca, on which the country currently depends for its international trade with European countries [48]. In June 2017, China officially declared the routes of the Arctic Ocean as part of its BRI and, since then, has started to cooperate with Arctic states, i.e., through high-level Chinese officials' visits to the Arctic Ocean [49].

\subsection{The Ground of Polar Silk Road (PSR) Gains}

The Chinese have engaged in cooperation and dialogue with Russia in developing the infrastructure related to the routes of the North Sea for the major Chinese-Russian natural gas projects on the Yamal peninsula [50]. In addition, China has intensified cooperation and dialogue in the region with regard to Iceland and Finland. Iceland is also considering identifying itself as a logistical "hub" on the PSR, which, according to China's white paper, has become the term for the Chinese vision of Arctic Ocean routes [51]. Preliminary negotiations are currently underway in Finland to create a 10,500 km cable through the Arctic to ensure the fastest data connection between Europe and China [52]. In addition, Norway and Finland have started collaboration on an "Arctic Corridor", comprising railway lines from Kirkenes in Norway to Rovaniemi in Finland, which has been indicated as a possible terminus of the PSR [53]. In addition, China also has growing interests in Sweden (in Lysekil), where Chinese corporations want to invest in the expansion project of ports and the construction of roads, bridges, and railways, concerning the necessary surrounding infrastructure of the port of Lysekil, which links to the PSR [54].

All these are potential major Chinese investments; these projects are linked to the recognition of the BRI, which is likely to lead China's commercial banks and companies, as well as other involved parties, having a greater chance of obtaining funding, i.e., from the Silk Road Fund, the Chinese state investment fund, and will probably mean they can count on political support. The Arctic policy of China through the white paper clearly encourages Chinese corporations to prioritise involvement in the construction of infrastructure related to routes of the Arctic Ocean and stresses that China is willing to work with any Arctic state interested in developing the PSR [47].

The aforementioned shows that China intends to cooperate with all stakeholders to construct the PSR by developing various shipping routes in the Arctic Ocean [55]. The recent Chinese white paper emphasised the special status of the Arctic Ocean, as it is an oceanic region that includes areas within states' jurisdictions as well as areas within universal scope, making it a region that has the interest of both Arctic and non-Arctic states. Intrinsically, Arctic problems are not only national or internal problems for the Arctic states but also international concerns. As stated in China's Arctic policy, the current situation concerning various activities in the Arctic Ocean not only affects the Arctic states internally or the relations between Arctic states. Beyond the Arctic states, it has "global impact" and "critical impact" on the development, sustainability, and survival of all states, including China [56].

\section{Existing International Treaties Regarding Fishery Issues in the Arctic Ocean}

UNCLOS provides that any coastal state has a right over fishing and other coastal activities extending up to 200 nautical miles from its coastal baseline. According to Article 87 of UNCLOS, vessels of all states have the right to fish in the areas on the high seas, unless they have entered into an international agreement in which otherwise is stipulated. Several international legal instruments, in some way, address issues concerning fishing in the Arctic Ocean region. Among these, the most recent development is that, on 3 October 2018, the governments of China, Korea, Japan, Canada, Norway, Iceland, Denmark, the Russian Federation, the EU, and the US, signed an agreement to prevent unregulated 
commercial fishing on the high seas in the Arctic region [57]. This is the first agreement of its kind to apply a legally binding precautionary approach for the protection of the Arctic Ocean from commercial fishing before fishing begins in that area.

According to this agreement, the contracting parties undertake not to participate in commercial fishing in the $\mathrm{CAO}$ until a better understanding exists concerning the current fish stocks in the Arctic Ocean region. The parties under the agreement will set up joint monitoring and scientific research programmes to enhance understanding of the ecosystems of the Arctic region and determine whether the fish stocks can be harvested sustainably [58]. This programme should provide the contracting parties appropriate time to develop a better understanding of the marine species and ecosystems in the region in order to inform them about protection and governance measures. After this agreement is enforced, it will actively last for 16 years and be renewed every five years thereafter, subject to the mutual consent of the parties and must address any party objecting $[59,60]$. It is perceived that the $\mathrm{CAO}$ fisheries administration covers much beyond the fisheries, including cooperative Arctic governance and relations between the Arctic and non-Arctic states, as well as among the Arctic states [8]. Any fishing activity in $\mathrm{CAO}$ will couple with some negative impacts on the fish stock and the agreement creates an unusual avenue of participation that is based on caution rather than response. Eventually, such an arrangement could be more of a matter of diplomatic relations and states' politics. In addition, some scientists and states have shown their concerns and indicated that a CAO fisheries agreement is not necessary or urgent as there is no fishing activity or evidence that such activity could start in the foreseeable future [6]. Similarly, Young and Kim (2013) argued that the level of activity in the Arctic Ocean, particularly in relation to the high seas, was overestimated-the level of fear concerning gaps in the governance system of the Arctic Ocean region is largely predictive of diverting the world's energies to a grey area [17]. Such a scenario comprising the lack of scientific knowledge of the $\mathrm{CAO}$ species coupled with the unpredictable marine ecosystem could be catastrophic. Since China has a diplomatic history to carefully consider, it must address all reservations before ratifying any global agreement it has signed in light of best national interests. Nine out of ten signatories of this agreement had already ratified it, and in May 2021, after due consideration, China has also ratified this agreement, thus it came into force in June 2021 for the next 16 years [61]. Many regional authorities have already considered and developed measures concerning the governance and conservation of exploration fishing [62]. A collection evaluation of the present measures will represent a first step in the additional development of the governance and conservation measures for the control of exploratory fishing in the Arctic region.

\subsection{The US-Canada Bilateral Fisheries Management Agreements}

The US shares coastal borders with Canada at the Great Lakes and in three oceansthe Atlantic, the Pacific, and the Arctic Ocean. In these economically and ecologically significant regions, they share several important fishing resources and, at the same time, also face complex challenges in terms of conservation and governance. Given this situation, the US has been negotiating with Canada to sign several formal treaties and agreements that will facilitate collaboration on these shared fishing resources in the Arctic Ocean region. These governance measures also include three bilateral commissions, namely the Pacific Salmon Commission (PSC), the International Pacific Halibut Commission (IPHC), and the Great Lakes Fisheries Commission (GLFC) [63]. They have also made arrangements to ensure sustainable governance and fair access to other important marine resources, including Pacific hake/whiting and Pacific albacore [64]. Similarly, various activities and recent legal developments concerning the Arctic Ocean region and the newly discovered fish resources due to the rapid ice melting over recent years are also of great importance and concern not only to the US and Canada but to all the Arctic states. 


\subsection{International Instruments Concerning Fishing Regulations}

International fishing law has emerged as a body of law on the basis of some binding and nonbinding global legal instruments on appropriate regulations [65]. There are some legally binding instruments: treaties and agreements that are concluded in writing by states and international organisations to affix obligations and create legal rights. Such instruments are known as "hard laws" since the provisions of such instruments are legally binding on the contracting parties once they come into force. In contrast, nonbinding legal instruments offer guidelines for states and are generally known as "soft laws" because the provisions of these instruments do not bind the contracting parties [65]. The UN has played a key role in facilitating the adoption of some global instruments concerning the conservation and governance of fisheries resources through its specialised agencies, including the Food and Agricultural Organisation (FAO), and even directly [66].

In addition to the above, the FAO has also put in place four International Action Plans (IPOAs) to address the various issues raised in its negotiations. These are generally non-legally binding measures, such as the Code of Conduct for Responsible Fisheries, that contain measures to primarily address several persistent issues, including combating Illegal, Unreported, and Unregulated (IUU) fishing, the bycatching of seabirds in longline fisheries, the governance and conservation of marine species such as sharks, fishing, and capacity management $[67,68]$. These different IPOAs address various pertinent issues, which include IPOA-IUU fishing, IPOA-fishing capacity, IPOA-sharks, and IPOA-sea birds. By accepting any IPO, states can ensure that other states increase the measures they are taking. The implementation of any IPO is voluntary and it is left to states to take explicit appropriate measures, including addressing problems that arise both in the exclusive economic zone (EEZ) and on the high seas [65]. Several international treaties deal with specific Arctic issues and are particularly relevant to the treatment of various Arctic issues. These agreements are presented here in chronological order, in Table 2.

Table 2. International agreements that directly or indirectly concern fisheries in the Arctic Region.

\begin{tabular}{|c|c|}
\hline Sr. No. & Name of the Agreement \\
\hline 1 & Svalbard Treaty, Paris, 9 February 1920 \\
\hline 2 & The International Convention for the Regulation of Whaling, Washington 1946 \\
\hline 3 & Geneva Conventions on the Law of the Sea, 1958 \\
\hline 4 & UN International Convention on the Elimination of All Forms of Racial Discrimination, 1965 \\
\hline 5 & UN International Covenant on Civil and Political Rights, 16 December 1966 \\
\hline 6 & International Covenant on Economic, Social, and Cultural Rights, 16 December 1966 \\
\hline 7 & $\begin{array}{l}\text { Convention on International Trade in Endangered Species of Wild Fauna and Flora (also called the CITES or } \\
\text { Washington Convention), Washington, US, } 1973\end{array}$ \\
\hline 8 & Agreement on the Conservation of Polar Bears, Oslo, 15 November 1973 \\
\hline 9 & The Convention on Long-range Transboundary Air Pollution, Geneva, 1979 \\
\hline 10 & The Convention on the Conservation of Antarctic Marine Living Resources, 1980 \\
\hline 11 & UN Convention on the Law of the Sea (UNCLOS) Montego Bay, Jamaica, 10 December 1982 \\
\hline 12 & Indigenous and Tribal Peoples Convention, (also called the ILO Convention No. 169 or C169), 1989 \\
\hline 13 & Convention on Environmental Impact Assessment in a Transboundary Context (Espoo Convention), Espoo, 1991 \\
\hline 14 & UN Framework Convention on Climate Change (UNFCCC), New York City, US, 4 June 1992 \\
\hline 15 & UN Convention on Biological Diversity, Rio de Janeiro (BR), May 1992 \\
\hline 16 & $\begin{array}{c}\text { Agreement to Promote Compliance with International Conservation and Management Measures by Fishing Vessels on } \\
\text { the High Seas, } 1993\end{array}$ \\
\hline 17 & FAO Code of Conduct for Responsible Fisheries, 1995 \\
\hline 18 & The UN Fish Stocks Agreement, 1995 \\
\hline
\end{tabular}


Table 2. Cont

\begin{tabular}{cr}
\hline Sr. No. & Name of the Agreement \\
\hline 19 & Kyoto Protocol to the UNFCCC, Kyoto, Japan, 11 December 1997 \\
\hline 20 & Stockholm Convention on Persistent Organic Pollutants, 2001 \\
\hline 21 & International Convention for the Control and Management of Ships' Ballast Water and Sediments, 2004 \\
\hline 22 & Agreement on Port State Measures to Prevent, Deter, and Eliminate Illegal, Unreported, and Unregulated Fishing, 2009 \\
\hline 23 & Agreement on Cooperation on Aeronautical and Maritime Search and Rescue in the Arctic, Nuuk, Greenland, 2011 \\
\hline 24 & Un Environmental Programme Minamata Convention on Mercury, 2013 \\
\hline 26 & Agreement on Cooperation on Marine Oil Pollution Preparedness and Response in the Arctic, Kiruna, Sweden, 2013 \\
\hline 28 & Agreement on Enhancing International Arctic Scientific Cooperation, signed at the Fairbanks Ministerial meeting, 11 \\
\hline 29 & International Agreement to Prevent Unregulated High Seas Fisheries in the Central Arctic Ocean, 3 October 2018 \\
\hline
\end{tabular}

\section{The Logic and Reasoning of China's Future Role in the Arctic}

China identifies itself as a near-Arctic state and emphasises that "China is an important stakeholder in Arctic affairs." Based on these two important narratives, China is primarily concerned with Arctic environmental conditions and the possible impact the region has on the Chinese climate system, the environment, and related economic interests [56]. With a forward-looking vision, China claims to lead the way towards a shared future for humanity by increasing involvement in Arctic affairs and contributing to Arctic knowledge and development in its economic and research activities [43]. It can be seen in China's recent fiveyear plan for 2016-2020, which closed the gap between itself and many Arctic states. For example, China now has two polar icebreakers and more scientific infrastructure capacities in the Arctic than any other non-Arctic state, including the Yellow River Station in Svalbard, the China-Island Arctic Observatory, and the Xuelong and Xuelong 2 icebreakers [69].

\subsection{Current Arctic Legal Regime and the Future Role of China}

Changes to fishery stock compositions and distributions can result in conflicts between stakeholders of the Arctic due to various reasons, including unregulated fishing, overlapping jurisdictional claims, and a lack of multiregional agreements. The current Arctic fisheries management model is not flexible enough to meritoriously address the challenges of future fisheries caused by climate change. It merits a comprehensive law and order regime in the high seas in connection with environmental protection, especially to vulnerable indigenous peoples and the whole world at large.

Climate change has been challenging the effectiveness of the existing structure of international resource management in the Arctic Ocean. For example, in fisheries management, the matters relating to quota allocation and access to the EEZs tend to be a highly controversial issue anytime; therefore, this problem should be resolved by a broader and more robust set of compliance mechanisms. Presently, the basis for a legal framework in the region is the UNCLOS of 1982 and the United Nations Fish Stocks Agreement (UNFSA) of 1995 (broadly followed by the recent CAO Agreement in 2018); however, these provide principles of international cooperation in conservation and fisheries management but do not formalise the way states use them [70]. Therefore, considering the fact that the Arctic is warming faster than any other area on Earth [71], this complex region requires a special and shared legal regime to achieve sustainable development goals.

China's future Arctic policy as demonstrated by Chinese officials includes six specific points, namely (1) exploring and further understanding the Arctic, (2) protecting and using the Arctic rationally, (3) respecting the internal rights of the Arctic states and indigenous 
peoples, (4) respecting the rights of non-Arctic states and the general interests of the global community, (5) building a multilevel framework for cooperation in the Arctic for winwin outcomes, and (6) supporting the Arctic governance system on the basis of existing international law [33]. The Arctic has the potential to provide solutions to domestic problems, including food production and energy security. This is because the Arctic, which is warming twice as fast as the rest of the world, provides a unique environment for food security research and options for importing food sources such as uncovered fish and Arctic seafood, as well as active oil and gas mining projects in China [72].

In addition to natural resources, China has a great practical interest in developing a long-term transport infrastructure through its vision of the PSR - an extension of the Chinese BRI [73]. The principle of the BRI is to create a network of roadways, railways, oil pipelines, and ports that may connect Beijing to Europe via the Middle East [73]. To this end, China has identified around 900 projects with an estimated cost of USD 900 billion within the framework of the BRI [74]. However, China's Arctic strategy on fishery resources is only beginning to evolve and still faces many challenges. Therefore, it underlines a key issue - cooperation - to mutually recognise the right of states to discover and release the potential of Arctic fish [22].

The white paper combines two provocative components of Chinese politics: adherence to the principles formulated by the Arctic Council and existing laws, while also aiming to defend the legitimate rights of non-Arctic states and improving legislation favouring better openness. The logical and practical approach that enabled China to develop diverse diplomacy towards the Arctic states implies clear arguments for interpreting the laws and key instruments-participation in Arctic governance, access to Arctic fishery resources, and global transport via the Arctic route [56]. Incidentally, despite its commitments to the existing legal system, China will be an activist for the rights of non-Arctic states in a situation conducive to legal change. Ultimately, if successful in this area, it will dramatically impact awareness of China's new role both in the Arctic and globally.

\subsection{The Exploitation of Fishery Resources in the $C A O$}

It is a fact that the Arctic periphery is exceptionally rich in fishing resources: the Bering region, Baffin Bay, the Chukchi, and the Barents Sea are fishing areas with an abundance of commercial species-they provide around $20 \%$ of the world catch-such as cod, which are targeted by Spanish fishermen [75]. Therefore, it seems clear that as the ice recedes, the newly opened waters will be just as rich. However, the worst part is that the waters are very stratified, with cold, soft water from the melting ice remaining on top of the warmer and saltier water, inhibiting the increase of nutrients from the soil. This is combined with the lack of ports to unload, ship, and process the catches, along with the Arctic Ocean's acidification because, paradoxically, cold water absorbs more CO2 than warm water, and the misunderstood phenomenon of anomalous abundance and pollutants, meaning the apparent promise of bountiful catches has little support [76].

China is committed to improving and complementing the Arctic governance regime [36]. It should be noted that Arctic governance must be an integrative, holistic, and adaptive ecosystem with transboundary dimensions due to its complexity in the Arctic [77]. The governance of maritime transport is, in fact, one of the dimensions of Arctic governance. In a broader sense, China believes that the UN Charter and UNCLOS are essential elements of the basic legal framework for navigation in the Arctic [43]. Specifically, China considers the IMO as the global standard-setting authority for international maritime transport security, safety, and environmental performance and recognises that IMO plays an active role in formulating navigation rules for maritime transport in the Arctic. At present, actively participating in the governance of Arctic maritime transport is China's strategy for action at a global and a regional level [78]. 


\subsection{China's Future Attitudes Reflected by Its Arctic Policy}

The impacts of developments and climate change in the region have pushed China to step up its efforts in the far north for a longer perspective [79]. In 2013, China became an observer to the Arctic Council with clear interests in the Arctic: use of the northern route, access to the natural resources of the Arctic, and working together to strengthen its image as one of the major powers. To this end, China has been investing heavily in projects in almost all Arctic countries [80]. In addition, China is expanding its research capabilities in this region; the Arctic strategy includes highlighting the two icebreaker research vessels and research stations in Norway and Iceland [81].

It has been reported that China is building or has built several hard-hull cargo ships. Additionally, at a recent trade fair in Shanghai, China showed models of its newly built ice-resistant LNG carriers [82]. The design and construction of polar ships have been China's political objective since 2016, starting with the thirteenth five-year plan [80]. It is due to the fact that regular use of the northern route would be an economic boom for China because the distance between German and Shanghai ports via the northern route is over $4600 \mathrm{~km}$ shorter than via the Suez Canal [83].

It can be said that China's interests concerning the various activities in the Arctic are principally economic, particularly energy cooperation with Russia. To this end, in order to strengthen energy security and reduce its dependence on coal for power generation, in December 2019, China inaugurated the 3000 km "Power of Siberia" gas pipeline connecting northeast China with Russia's Siberian fields [84]. In addition, Chinese enterprises are also playing a significant role in building the Arctic LNG 2 project, which is the second largest natural gas project presently undergoing development phase within the Russian Arctic [85].

\subsection{Why China Needed an Arctic Policy}

First, climate change is a major concern in the Arctic and an important rationale for China's involvement in Arctic affairs. Indeed, the Arctic suffers from human-induced climate change and is witnessing the rapid melting of permafrost and the collapse of sea ice [86]. Meanwhile, China is the world's largest emitter of greenhouse gases [87], while also faces major climate change challenges, such as extreme weather conditions [88]. China's Arctic policy in 2018 promised to tackle climate change in the Arctic and protect its fragile environment, but details are lacking. In 2020, Chinese President Xi Jinping announced to the UN General Assembly that China is committed to being carbon neutral by 2060 [89]. This is a very ambitious step in the fight against climate change. However, some questions remain unclear and will be answered in the subsequent research concerning how this will affect the Arctic. What kinds of projects on the Polar Silk Road in China can help achieve this ambitious goal? Would Chinese investment in Arctic resource development conflict with China's zero greenhouse gas emissions roadmap? These are key issues that require clarification in China's Arctic policy [90].

Second, sustainability is another important theme for the future of the Arctic. China stresses the need to strike a balance between economic development and environmental protection in the Arctic. This is reflected in the negotiations of collective labour agreements, where China speaks of "wise use". However, terms like "sustainable development" and "balance" are subject to potentially conflicting interpretations. What exactly does China mean by equilibrium? It is not just about deep-sea fishing, but almost all Chinese activities in the Arctic. Given the fragile Arctic ecosystem, one would expect a balance between use and protection to shift towards the environment.

In sum, it is time for China to expedite and clarify its constructive ambitions as outlined in the Arctic Policy to shed light on the order that it would like to address the issues in the Arctic with its emerging power. Suppose China, the world's second-largest economy, can develop a vision based on a reinvention of the relationship between humans and nature, supported by a concrete plan. In this case, it will not only help propel the Arctic towards a peaceful and sustainable future, but will also benefit the rise of China in the region and across the globe. 


\subsection{Criticism of China's Arctic Policy and Global Concerns}

Over the last decade, China's Arctic engagement has increased considerably, aiming to offer plentiful economic opportunities. On the other hand, some critics believe that by doing so, China is likely to create new risks and concerns among the eight Arctic states [91]. Similarly, the US has been seriously concerned as China expands its engagements in the Arctic Ocean region; the implications of its activities and even its presence are an increasingly debated topic among the Arctic states, in the US, and across the globe [92]. The US Secretary of State and the Department of Defence publicly raised concerns on China's self-proclaimed status as a "near-Arctic state" [83]. China has claimed compassionate intentions in sustainable development, peace, and improving Arctic governance [93]. However, given the opacity of China's decision making and capability development, many observers and policymakers in the US remain sceptical or even hostile toward China's potential interests in the Arctic; strategic thinkers in the US worry that China's economic engagement in the region could be a precursor to much more invasive political and strategic ambitions [94]. The fact that China's Arctic infrastructure development has the potential for dual-use facilities increases the insecurities that China may intend to have a permanent security presence in the region.

In addition, the fact that Some Arctic states have welcomed chinese economic activities in the Arctic is worrying to the European Parliament and thinktanks too, and they believe that China is interested in a narrow interpretation of its claims and the largest possible interpretation of maritime space in the Arctic Ocean considered as the high seas and international seabed, where non-Arctic states have the same rights as Arctic states [95]. They also believe that China is interested in expanding its BRI into the Arctic to facilitate the strengthening of its claims of co-existence with economic and sustainable development coupled with its participation in Arctic governance affairs, including respect, cooperation, and win-win outcomes. Despite all the critics, if China keeps its word and focuses only on promoting research, peace, and sustainable development, it would obviously be a win-win situation for China, Arctic states, and other stakeholders in the long run.

\section{Conclusions}

The world, including the Arctic and non-Arctic states, is looking for fisheries resources to meet the requirement for more food and are now considering the potential of the Arctic Ocean as a result of increasing access, due to the melting of the ice cap. Similarly, China is also strategically considering this area from the perspective of the economy as well as ecological and resource governance measures. To this end, China's emerging interest in the circumpolar north was established with the Chinese Arctic policy, as laid down in its white paper. The clear and articulated objectives, priorities, and principles have become a guide for the further development of Arctic politics and international cooperation, concerning all political actors' efforts. More notably, the white paper confirmed China's aim to construct the PSR and identified Arctic participation, conversation, protection, and governance as the crucial areas of Arctic policy, being on par with other regional development since the creation of the PSR will combine economic effort, while also confirming China's national interest in the implementation of such policies in the Arctic. As a result, Arctic governance will tie together the development of intangible mechanisms: legislative and institutional involvement and contribution, which include China's "discursive power".

In addition, the analysis of China's Arctic policy white paper enables the establishment of principles that will form the core of Chinese Arctic policy in the future. The first component that reflects the image is that China is an "important and legitimate stakeholder", a "responsible power" and a "near-Arctic state". The second is an affirmation of the Chinese right to participate in the governance of the Arctic Ocean and to develop Arctic shipping and marine resources, and, consequently, China's obligation to defend the legal rights of a "near-Arctic state", creating a right to access the Arctic resources including fishing, as with the other Arctic states. Thirdly, the intention to make a contribution toward an "Arctic 
community with a shared future" [96] through the implementation of the PSR. Such a combination will be at the centre of China's Arctic policy both now and in the future.

Additionally, it is also pertinent to note that China has become one of the major stakeholders in Arctic Ocean governance as adhered by the Agreement to prevent unregulated commercial fishing on the high seas in the Arctic region. However, there is still enough room for improving the effectiveness of the legal framework governing the Arctic-the absence of a shared legal regime. This status will not only enable China to influence environmental governance but also provide access-as one of the key players-to the Arctic fisheries resources in the future. To this end, China has long been focusing on this area through investing in various sectors, including infrastructure development and economic and food security research and development, contributing towards novel shipbuilding technologies, i.e., ice-resistant LNG carriers and polar ships, which is a positive and peaceful strategy towards participation in resources development, protection, and ocean governance across the regions and the globe. If China handles these transactions successfully and peacefully, sustaining them with mutual cooperation in the future, it may enable China-a resourceful continental state closest to the Arctic circle - to obtain a legal right to fish in the Arctic considering its significant stake and contribution to building a sustainable future Arctic, including huge investments in the development of relevant sectors, research and governance endeavours, and efforts towards ensuring environmental security, as well as sustainable use of the Arctic fisheries resources, and so on. Concluding, China has shaped its Arctic policy very tactfully, claiming legal rights over fisheries resources and gaining global acknowledgement of its co-existence in Arctic governance; it will also be backed by and considerably strengthen China's strategic Polar Silk Road vision as well as the Belt and Road Initiative in the long run.

Author Contributions: M.I.K. deals with substantial writing up and revisions; Y.-C.C. provides general guidance and arranged the funds. Conceptualization, M.I.K. and Y.-C.C.; methodology, M.I.K.; formal analysis, M.I.K.; investigation, M.I.K.; resources, M.I.K. and Y.-C.C.; writing-original draft preparation, M.I.K.; writing-review and editing, M.I.K.; supervision, Y.-C.C.; funding acquisition, Y.-C.C. All authors have read and agreed to the published version of the manuscript.

Funding: The field work is supported by the following project: The National Social Science Fundamental Project, China, 'Research on China's Maritime Rights Protection under the Perspective of Maritime Community with the Shared Future' (Grant No. 19VHQ009).

Institutional Review Board Statement: Not applicable.

Informed Consent Statement: Not applicable.

Data Availability Statement: Not applicable.

Conflicts of Interest: The authors declare that there is no known conflict of interest.

\section{References}

1. Perovich, D.; Meier, W.; Tschudi, M.; Farrell, S.; Hendricks, S.; Gerland, S.; Haas, C.; Krumpen, T.; Polashenski, C.; Ricker, R.; et al. Arctic Report Card: Update for 2018-Effects of Persistent Arctic Warming Continue to Mount. Available online: https: / arctic. noaa.gov/Report-Card/Report-Card-2018/ArtMID/7878/ArticleID/780/Sea-Ice (accessed on 23 January 2020).

2. Huntington, H.P.; Carmack, E.; Wassmann, P.; Wiese, F.; Leu, E.; Gradinger, R. A New Perspective on Changing Arctic Marine Ecosystems: Panarchy Adaptive Cycles in Pan-Arctic Spatial and Temporal Scales; Cambridge University Press: Cambridge, UK, 2015; ISBN 9781316164624.

3. Melia, N.; Haines, K.; Hawkins, E. Improved Arctic sea ice thickness projections using bias-corrected CMIP5 simulations. Cryosphere 2015, 9, 2237-2251. [CrossRef]

4. Jones, M.C.; Cheung, W.W.L. Multi-model ensemble projections of climate change effects on global marine biodiversity. ICES J. Mar. Sci. 2015, 72, 741-752. [CrossRef]

5. Mueter, F.J.; Litzow, M.A. Sea ice retreat alters the biogeography of the Bering Sea continental shelf. Ecol. Appl. 2008, 18, 309-320. [CrossRef] [PubMed]

6. Hollowed, A.B.; Planque, B.; Loeng, H. Potential movement of fish and shellfish stocks from the sub-Arctic to the Arctic Ocean. Fish. Oceanogr. 2013, 22, 355-370. [CrossRef] 
7. Molenaar, E.J. The Oslo Declaration on High Seas Fishing in the Central Arctic Ocean. Available online: https://arcticyearbook. com/arctic-yearbook/2015/2015-briefing-notes/159-the-oslo-declaration-on-high-seas-fishing-in-the-central-arctic-ocean (accessed on 3 July 2021).

8. Pan, M.; Huntington, H.P. A precautionary approach to fisheries in the Central Arctic Ocean: Policy, science, and China. Mar. Policy 2016, 63, 153-157. [CrossRef]

9. Bailey, K.M. An Empty Donut Hole: The Great Collapse of a North American Fishery. Ecol. Soc. 2011, 16, 28. [CrossRef]

10. Ianelli, J.N.; Hollowed, A.B.; Haynie, A.C.; Mueter, F.J.; Bond, N.A. Evaluating management strategies for eastern Bering Sea walleye pollock (Theragra chalcogramma) in a changing environment. ICES J. Mar. Sci. 2011, 68, 1297-1304. [CrossRef]

11. GoC International Agreement to Prevent Unregulated High Seas Fisheries in the Central Arctic Ocean. Available online: https://www.dfo-mpo.gc.ca/international/arctic-arctique-eng.htm (accessed on 3 July 2021).

12. Vylegzhanin, A.N.; Young, O.R.; Berkman, P.A. The Central Arctic Ocean Fisheries Agreement as an element in the evolving Arctic Ocean governance complex. Mar. Policy 2020, 118, 104001. [CrossRef]

13. Tang, X.; McLellan, B.C.; Snowden, S.; Zhang, B.; Höök, M. Dilemmas for China: Energy, economy and environment. Sustainability 2015, 7, 5508-5520. [CrossRef]

14. Jensen, $\varnothing$. The Svalbard Treaty and Norwegian Sovereignty. Available online: https://doi.org/10.23865/arctic.v11.2348 (accessed on 3 July 2021).

15. Pan, M. Study of favorable factors, barriers and coping strategies of China's participation in the Arctic affairs. China Soft Sci. 2013, $6,115$.

16. Snow Dragon's maiden voyage to the Arctic: Chinese ships connect the North Pacific and North Atlantic waters through the Arctic route for the first time. Beijing News 2012, 14, 145.

17. Young, O.R.; Kim, J.D.; Kim, Y.H. (Eds.) The Arctic in World Affairs: A North. Pacific Dialogue on the Future of the Arctic; Korea Maritime Institute and the East-West Center: Seoul, Korea, 2013; ISBN 9788979989397.

18. The Russia Beyond China to provide Total with $\$ 15$ billion for development of Yamal LNG plant. Russ. Beyond $2015,14,1465$.

19. Lajeunesse, A. Chinese Mining Interests and the Arctic. In Governing the North American Arctic; Berry, D.A., Bowles, N., Jones, H., Eds.; St Antony's Series; Palgrave Macmillan: London, UK, 2015.

20. Staalesen, A. Chinese Mining Interests and the Arctic. Barents Obs. 2015, 14, 5574.

21. FOA-China FAO + China: Partnering for Sustainable Food Security. Available online: http://www.fao.org/3/ca4948en/ca494 8en.pdf (accessed on 23 October 2020).

22. Hong, N. China's Interests in the Arctic: Opportunities and Challenges Examining the Implications of China's Arctic Policy White Paper; Institute for China-America Studies: Washington, DC, USA, 2018.

23. Young, O.R. Is it time for a reset in Arctic governance? Sustainability 2019, 11, 4497. [CrossRef]

24. MFA-China Keynote Speech by Vice Foreign Minister Zhang Ming at the China Country Session of the Third Arctic Circle Assembly. Available online: https:/ / www.fmprc.gov.cn/mfa_eng/wjbxw/t1306858.shtml (accessed on 23 October 2020).

25. Liu, N. China's emerging Arctic policy: What are the implications for Arctic governance? Jindal Glob. Law Rev. 2017, 8, 55-68. [CrossRef]

26. UNCLOS. The United Nations Convention on the Law of the Sea. Available online: http://www.un.org/Depts/los/convention_ agreements/convention_historical_perspective.htm (accessed on 18 October 2021).

27. Hossain, K. China's White Paper on the Arctic: Legal Status Under International law. Am. Soc. Int. Law 2018, $22,145$.

28. Hong, N. Emerging interests of non-Arctic countries in the Arctic: A Chinese perspective. Polar J. 2014, 4, 271-286. [CrossRef]

29. Ingimundarson, V. Managing a contested region: The Arctic Council and the politics of arctic governance. Polar J. 2014, 4, 183-198. [CrossRef]

30. Moe, A.; Stokke, O.S. Asian countries and arctic shipping: Policies, interests and footprints on governance. Arct. Rev. Law Polit. 2019, 10, 24-52. [CrossRef]

31. Javed, T. China's Arctic Policy. Cent. Strateg. Contemp. Res. 2018, 78, 8564.

32. Liu, N. How Has China Shaped Arctic Fisheries Governance? Sustainability 2018, 15, 8547.

33. Lim, K.S. China's Arctic Policy \& the Polar Silk Road Vision. Arct. Yearb. 2018, 420-437.

34. Lanteigne, M. Not Stopping Cold: China's Emerging Strategies in the Arctic. Available online: https://centreasia.hypotheses. org / 653 (accessed on 23 October 2020).

35. Haug, T.; Bogstad, B.; Chierici, M.; Gjøsæter, H.; Hallfredsson, E.H.; Høines, Å.S.; Hoel, A.H.; Ingvaldsen, R.B.; Jørgensen, L.L.; Knutsen, T.; et al. Future harvest of living resources in the Arctic Ocean north of the Nordic and Barents Seas: A review of possibilities and constraints. Fish. Res. 2017, 188, 38-57. [CrossRef]

36. China's Information Office China's Arctic Policy: White Paper. Available online: http://www.scio.gov.cn/zfbps/32832/ Document/1618203/1618203.htm (accessed on 23 October 2020).

37. MOFA-PRC UN Climate Action Summit: China's Position and Action. Available online: https://www.fmprc.gov.cn/mfa_eng/ wjdt_665385/2649_665393/t1698088.shtml (accessed on 23 October 2020).

38. United Nations “The Paris Agreement 2015", Entered into Force on 4 November 2016. Available online: https://treaties.un.org/ Pages/ViewDetails.aspx?src=TREATY\&mtdsg_no=XXVII-7-d\&chapter=27\&lang=_en\&clang=_en (accessed on 14 March 2019).

39. Kyoto Protocol Kyoto Protocol-Targets for the First Commitment Period. Available online: https://unfccc.int/process/the-kyotoprotocol (accessed on 23 November 2018). 
40. United Nations. United Nations Framework Convention on Climate Change: Resolution/adopted by the General Assembly. 20 January 1994. Available online: http:/ / www.refworld.org/docid/3b00f2770.html (accessed on 5 May 2018).

41. UNCC. China Submits its Climate Action Plan Ahead of 2015 Paris Agreement. Available online: https://unfccc.int/news/chinasubmits-its-climate-action-plan-ahead-of-2015-paris-agreement (accessed on 24 October 2020).

42. IMO. Reducing Greenhouse Gas Emissions from Ships. Available online: https://www.imo.org/en/MediaCentre/HotTopics/ Pages/Reducing-greenhouse-gas-emissions-from-ships.aspx (accessed on 24 October 2020).

43. Xinhua Full text: China's Arctic Policy. China Dly. 2018, 45, 54.

44. Hong, N. China's New Arctic Policy: Legal Questions and Practical Challenges. Available online: https://www.nbr.org/ publication/chinas-new-arctic-policy-legal-questions-and-practical-challenges/ (accessed on 22 August 2020).

45. Hong, N. How China's Arctic Policy Paper Has Warmed the Atmosphere with International Observers. Available online: https: / / www.ualberta.ca/china-institute/research/commentary/2018/february/chinas-arctic-policy-paper.html (accessed on 24 October 2020).

46. Burke, D.C. The Northwest Passage Dispute. Oxford Res. Gr. 2018, 78, 6956.

47. Camilla, S.; Yağci, M. China as an Arctic Great Power. Policy Br.-R. Dan. Def. Coll. 2018, 15, 67-78. [CrossRef]

48. Oxford Analytica Polar Silk Road will reshape trade and geopolitics. Oxford Anal. Dly. Br. 2018, 87, 4563.

49. Vision for Maritime Cooperation under the Belt and Road Initiative. Available online: http://www.china.org.cn/world/2017-06/ 20/content_41063286.htm (accessed on 22 August 2020).

50. Sørensen, C.T.; Klimenko, E. Emerging Chinese-Russian Cooperation in the Arctic. Possibilities and Constraints. Available online: https:/ / www.sipri.org/sites / default/ files/2017-06/emerging-chinese-russian-cooperation-arctic.pdf (accessed on 24 October 2020).

51. Guschin, A. China, Iceland and the Arctic. Sustainability 2015, 14, 145.

52. South China Morning Post China mulls joining scheme to lay telecom cable across Arctic Circle. South. China Morning Post 2017, 45,879 .

53. Tsuruoka, D. Finland could serve as China's Arctic gateway for Obor. Asia Times 2017, 54, 123.

54. Olsson, J. China's Bid to Build the Largest Port in Scandinavia Raises Security Concerns. Taiwan Sentin. 2017, $54,786$.

55. Xinmin, M.A. China's Arctic policy on the basis of international law: Identification, goals, principles and positions. Mar. Policy 2019, 100, 265-276. [CrossRef]

56. Mariia, K. China's Arctic policy: Present and future. Polar J. 2019, 9, 94-112. [CrossRef]

57. Levon Sevunts Scientists Urge International Agreement on Fisheries in Central Arctic Ocean. Available online: https:// thebarentsobserver.com/ru/node/3042 (accessed on 24 October 2020).

58. George, J. A new international deal protects the Central Arctic Ocean's fish stocks. Arct. Today 2018, 45, 245.

59. IISD Nine Countries, EU Sign Agreement to Prevent Unregulated Fishing in Central Arctic Ocean. Int. Inst. Sustain. Dev. 2018, 68,456 .

60. European Commission Preventing unregulated fishing in the Arctic: EU and partners meet to further the implementation of historic agreement. Eur. Comm. 2019, 45, 45.

61. Balton, D. Landmark Arctic Fisheries Agreement Enters into Force. Available online: https://www.maritime-executive.com/ editorials/landmark-arctic-fisheries-agreement-enters-into-force (accessed on 17 September 2021).

62. Ewell, C.; Hocevar, J.; Mitchell, E.; Snowden, S.; Jacquet, J. An evaluation of Regional Fisheries Management Organization at-sea compliance monitoring and observer programs. Mar. Policy 2020, 115, 103842. [CrossRef]

63. US-DOS. International Fisheries Management. Available online: https://www.state.gov/key-topics-office-of-marineconservation/international-fisheries-management/ (accessed on 24 October 2020).

64. US-NOAA. United States-Canada Albacore Treaty. Available online: https://www.fisheries.noaa.gov/west-coast/sustainablefisheries/united-states-canada-albacore-treaty (accessed on 24 October 2020).

65. Arif, A. Al An Introduction to International Fisheries Law Research. Available online: https://www.nyulawglobal.org/globalex/ International_Fisheries_Law.html\#InternationalInstrumentsonFisheriesRegu (accessed on 24 October 2020).

66. Harrison, J.; Lobach, T.; Morgera, E.; Manoa, P. Review and Analysis of International Legal and Deep-Sea Fisheries and Biodiversity Conservation in Areas Beyond National Jurisdiction; Food and Agriculture Organization of the United Nations and Global Environment Facility: Rome, Italy, 2017; ISBN 9789251097007.

67. UN-FAO. International Plans of Action. Available online: http://www.fao.org/fishery/code/ipoa/en (accessed on 24 October 2020).

68. Baird, R. Illegal, unreported and unregulated fishing: An analysis of the legal, economic and historical factors relevant to its development and persistence. Melb. J. Int. Law 2004, 5, 299-334.

69. Brady, A.M. China as a Polar Great Power; Cambridge University Press: Cambridge, CA, USA, 2017 ; ISBN 9781316832004.

70. Uryupova, E. Why Do We Need a Shared Pan-Arctic Fisheries Governance Complex? Available online: https://www. thearcticinstitute.org/need-shared-pan-arctic-fisheries-governance-complex/?cn-reloaded=1 (accessed on 25 October 2021).

71. Turton, S. Climate Explained: Why Is the Arctic Warming Faster than Other Parts of the World? Available online: https: //council.science/current/blog/climate-explained-why-is-the-arctic-warming-faster-than-other-parts-of-the-world/ (accessed on 22 October 2021). 
72. Li, X.; Peng, B. The Rise of China in the Emergence of a New Arctic Order. In The GlobalArctic Handbook; Finger, M., Heininen, L., Eds.; Springer: Berlin/Heidelberg, Germany, 2018.

73. The Economist explains: What is China's belt and road initiative? Economist 2017, 14, 2354.

74. Campbell, C. Ports, Pipelines, and Geopolitics: China's New Silk Road Is a Challenge for Washington. Time 2017, 45, 42.

75. del Pozo, F. The Exploitation of the Sea for Trade and Communication: The New Arctic Routes, Challenges, Conflicts and Prospects. In Security in the Global Commons and Beyond; Ramírez, M., Bauzá-Abril, B., Eds.; Springer International Publishing: Madrid, Spain, 2021; pp. 13-31. ISBN 9783030679736.

76. Loubere, P. The Global Climate System. Nat. Educ. 2012, 3, 24.

77. Platjouw, F.M. Dimensions of transboundary legal coherence needed to foster ecosystem-based governance in the Arctic. Mar. Policy 2019, 110, 103666. [CrossRef]

78. Zhang, Q.; Wan, Z.; Fu, S. Toward Sustainable Arctic Shipping: Perspectives from China. Sustainability 2020, 12, 9012. [CrossRef]

79. Lino, M.R. Understanding China's Arctic Activities. Available online: https://www.iiss.org/blogs/analysis/2020/02/chinaarctic (accessed on 15 August 2021).

80. Sengupta, S.; Myers, S.L. Latest Arena for China's Growing Global Ambitions: The Arctic. N. Y. Times $2019,4,25$.

81. Doshi, R.; Dale-Huang, A.; Zhang, G. Northern Expedition: China's Arctic Activities and Ambitions. Available online: https: / / www.brookings.edu/research/northern-expedition-chinas-arctic-activities-and-ambitions/ (accessed on 16 August 2021).

82. Eiterjord, T.A. China's Shipbuilders Seek New Inroads in Arctic Shipping. Time 2020, 14, 245.

83. Koh, S.L.C. China's strategic interest in the Arctic goes beyond economics. Def. News 2020, 10, 25.

84. Shao, G. Russia opens Siberian pipeline to China as Beijing expands its influence in the Arctic. Consum. News Bus. Channel 2019, $245,24563$.

85. Staalesen, A. Trans-Arctic shipments on agenda as Chinese companies come to St. Petersburg Economic Forum. Barents Obs. 2019, 78, 38 .

86. Canadian ice shelf area bigger than Manhattan collapses due to rising temperatures. Guard 2020, 54, 754.

87. Khan, M.I.; Chang, Y.C. Environmental challenges and current practices in China-A thorough analysis. Sustainability 2018, 10, 2547. [CrossRef]

88. Myers, S.L. After COVID, China's Leaders Face New Challenges From Flooding. New York Times 2020, $452,2456$.

89. Ambrose, J. China's carbon pledge will require complete inversion of existing system. Guard 2020, 57, 7856.

90. Liu, N. Why China Needs an Arctic Policy 2.0. Sustainability 2020, 25, 786.

91. Stewart, P.; Ali, I. Pentagon Warns on Risk of Chinese Submarines in Arctic. Available online: https://www.reuters.com/article/ us-usa-china-military-arctic-idUSKCN1S829H (accessed on 16 September 2021).

92. Humpert, M. Explaining China's Arctic Interests, the US' Efforts to Re-Engage, and the Growing Split Between the Two Countries. High North News 2019, 14, 547.

93. Hong, N. China's Role in the Arctic: Observing and Being Observed; Shibata, A., Zou, L., Sellheim, N., Scopelliti, M., Eds.; Routledge Research in Polar Law: New York, NY, USA, 2020.

94. Sun, Y. Defining the Chinese Threat in the Arctic. Available online: https:/ /www.thearcticinstitute.org/defining-the-chinesethreat-in-the-arctic/ (accessed on 16 September 2021).

95. Grieger, G. China's Arctic Policy: How China Aligns Rights and Interests. Available online: https:/ / www.europarl.europa.eu/ RegData/etudes/BRIE/2018/620231/EPRS_BRI(2018)620231_EN.pdf (accessed on 16 September 2021).

96. Zhang, W.; Chang, Y.C.; Zhang, L. An ocean community with a shared future: Conference report. Mar. Policy 2020, 116, 388. [CrossRef] 